\title{
Alpine forbs rely on different photoprotective strategies during spring snowmelt
}

\section{Fernandez-Marin, Beatriz}

$2021-07$

Fernandez-Marin , B , Saenz-Ceniceros , A , Solanki , T , Robson , T M \& Garcia-Plazaola , J I 2021 , 'Alpine forbs rely on different photoprotective strategies during spring snowmelt ' , Physiologia Plantarum , vol. 172 , no. 3 , pp. 1506-1517 . https://doi.org/10.1111/ppl.13342

http://hdl.handle.net/10138/339028

https://doi.org/10.1111/ppl.13342

acceptedVersion

Downloaded from Helda, University of Helsinki institutional repository.

This is an electronic reprint of the original article.

This reprint may differ from the original in pagination and typographic detail.

Please cite the original version. 


\title{
Alpine forbs rely on different photoprotective strategies during spring snowmelt
}

\author{
Beatriz Fernández-Marín ${ }^{a}$, Ana Sáenz , Twinkle Solankic, T. Matthew Robsonc, José Ignacio \\ García-Plazaolab*
}

aDept. Botany, Ecology and Plant Physiology, University of La Laguna (ULL), Tenerife 38200, Spain

${ }^{b}$ Dept. Plant Biology and Ecology, University of the Basque Country (UPV/EHU), Barrio Sarriena s/n, 48940 Leioa, Spain.

${ }^{\mathrm{c}}$ Organismal and Evolutionary Biology (OEB), Viikki Plant Science Centre (ViPS), Faculty of Biological and Environmental Sciences, University of Helsinki, 00014, Finland.

${ }^{*}$ Corresponding author,
email: joseignacio.garcia@ehu.eus

\begin{abstract}
Snowmelt in alpine ecosystems brings ample water, and together with above-freezing temperatures, initiates plant growth. In this scenario, rapid activation of photosynthesis is essential for a successful life-history strategy. But, strong solar radiation in late spring enhances the risk of photodamage, particularly before photosynthesis is fully functional. We compared the photoprotective strategy of five alpine forbs: one geophyte not particularly specialised in subnival life (Crocus albiflorus) and four wintergreens differing in their degree of adaptation to subnival life, from least to most specialised: Gentiana acaulis, Geum montanum, Homogyne alpina and Soldanella alpina. We used distance to the edge of snow patches as a proxy to study time-dependent changes after melting. We postulated that the photoprotective response of snowbed specialists would be stronger than of moregeneralist alpine meadow species. $F_{\mathrm{v}} / F_{\mathrm{m}}$ was relatively low across wintergreens and even lower in the geophyte C. albiflorus. This species also had the largest xanthophyll-cycle pool and lowest tocopherol and flavonoid glycoside contents. After snow melting, all the species progressively activated ETR, but particularly the intermediate snowbed species G. acaulis and G. montanum. The photoprotective responses after snowmelt were idiosyncratic: G. montanum rapidly accumulated xanthophyll-cycle pigments, tocopherol and flavonoid glycosides; while S. alpina showed the largest increase in plastochromanol-8 and chlorophyll contents and the greatest changes in optical properties. Climate warming scenarios might shift the snowmelt date and consequently alter the effectiveness of photoprotection mechanisms, potentially changing the fitness outcome of the different strategies adopted by alpine forbs.
\end{abstract}

\section{1-Introduction}

Alpine snowbeds can be considered extreme environments for plants. These habitats, covered by snow

This article has been accepted for publication and undergone full peer review but has not been through the copyediting, typesetting, pagination and proofreading process which may lead to differences between this version and the Version of Record. Please cite this article as doi: $10.1111 / \mathrm{ppl} .13342$ 
for most of the year, are located in places where snow accumulates for topographic or microclimatic reasons. Long-lasting snow cover has a dual effect on plants. On the one hand, it decreases freezing vulnerability because of the protective effect of snow, particularly during critical periods in spring (Körner 2003; Briceño et al. 2014). On the other hand, the heavy mass of snow imposes a series of physical and biological constraints on the plant life beneath, including a reduction in the vegetative period, anoxia and the facilitating spread of fungal infections (Körner 2003). As a consequence, these habitats foster a highly specialised flora (Körner 2003, Björk and Molau 2007, Leuschner and Ellenberg 2017), frequently dominated by hemicryptophytes (Ninot et al. 2013, Komac et al. 2015). Some of these species show unique characteristics such as the ability to re-start photosynthesis and growth weeks before snow melting is completed (Starr and Oberbauer 2003, Körner et al. 2019) or the high resistance to photoinhibition caused by the combination of high irradiance and low temperatures (Germino and Smith 2000). Overall, snowbed species show the highest degree of adaptation to subnival life.

Snowbeds are particularly vulnerable to climate warming (Matteodo 2016), both because this will bring an earlier date of snow melting and because a higher proportion of precipitation will occur as rain (Gobiet et al. 2014). Warmer conditions will change the micro-habitat in snowbeds as it is expected that early snowmelt will increase the risk of freezing damage to snowbed species that are intrinsically more freezing-sensitive than species inhabiting more-exposed sites (Bannister et al. 2005, Briceño et al. 2014, Wheeler et al. 2014). In addition, progressive warming of the climate will favour the replacement of highly specialised snowbed flora by more-competitive alpine meadow species (Schöb 2010, Tonin et al. 2019). In this sense, snowbed colonization by new species migrating from lower elevations, mainly driven by higher temperatures, is already evident in the Alps (Carbognari et al. 2014, Gristch et al. 2016) and likewise in the Snowy Mountains of Australia (Pickering et al. 2014). These reports describe changes in the plant community, while the ecophysiological drivers behind these changes have remained relatively poorly understood.

When plants (geophytes and hemicryptophytes) emerge from rapidly melting late-spring or earlysummer snow, they are suddenly exposed to extremely high doses of shortwave visible and UV radiation while temperatures are still close to $0{ }^{\circ} \mathrm{C}$. Additionally, both the high albedo of the receding snow pack and the relative enhancement of solar UV radiation at high elevations further increase the incident irradiance received by these plants (Blumthaler 2012). These conditions are potentially damaging to the photosynthetic apparatus because of an imbalance between light absorption and the capacity for photosynthetic utilisation (Huner et al. 1998, Germino and Smith 2000, Verhoeven 2013), and because of direct photodamage caused by the absorption of shortwave radiation (Takahashi and Badger 2011). Thereby, photoprotection is particularly critical to assure rapid re-establishment of photosynthesis and subsequent growth.

Some snowbed species regain photosynthetic function under snow, such as Soldanella alpina and Eriophorum angustifolium, others need some time to fully recover from their dormant state and a third 
group starts to produce new photosynthetic tissues under the snow (Lütz 1996, Körner 2003). Despite the high photoprotective requirement when snow melts rapidly and the leaves suddenly become exposed, few studies have specifically addressed the role of different protective mechanisms in snowbed plants (Lütz 1996, Germino and Smith 2000). Some snowbed species such as Soldanella alpina have powerful antioxidant defences, with very high pools of ascorbate and xanthophyll cycle pigments (Streb et al. 2003), while photoprotection is assured by a greater use of energy in others. This is the case for Geum montanum, which attains high rates of the cyclic electron transport (Manuel et al. 1999), Ranunculus glacialis with high chlororespiratory activity (Streb et al. 2005, Laureau et al. 2013) and Homogyne alpina through enhanced photorespiration and catalase activity (Streb et al. 1997, Lütz 2010). The upregulation of these mechanisms acts as a sink for the electron transport chain, providing a mechanism for reducing overexcitation and preventing PSII damage. Some of these protective responses alter chloroplast ultrastructure, leading to the appearance of specific features such as bigger plastoglobules (Bascuñán-Godoy et al. 2010) and chloroplast protrusions (Moser et al. 2015).

These studies of the ecophysiology of photosynthesis upon plant emergence from snow have deeply described photoprotection in a small set of alpine plant species, most of which were also used in the present study. However, most, if not all, of these studies have been performed at mid-summer, while much less is known about how photoprotective mechanisms respond to the changing conditions prevalent in late spring when these plants are first exposed to full sunlight and temperature fluctuations during snowmelt (Streb and Cornic 2012). With increasingly earlier snowmelt, the relevance of responses of these species following exposure during spring will become even greater. Comparisons between co-occurring snowbed species adopting more generalist vs strongly specialised strategies are also scarce and serve to illustrate the relative effectiveness of these different approaches. We, therefore, have aimed to characterise the role of photoprotection mechanisms in alpine plants during the critical period of snow melting in late spring, when solar irradiance is maximal. We postulate that the photoprotective responses of snowbed specialists must be different to those of moregeneralist alpine meadow species, with the former being constitutively stronger and the latter more plastic. To cover the range of biological strategies representative of this environment, we have studied the temporal responses after snow melting of four co-occurring evergreens whose leaves are retained over the whole winter season (including one "genuine” snowbed species, two "facultative” snowbed species, and one alpine meadow species) and of one geophyte that produces new leaves under the snow.

\section{2-Materials and methods}

\section{1-Field site, meteorological conditions, studied species and experimental design.}

Field measurements were performed in late spring 2019 (Julian days 148-151) on a south-facing slope in the vicinity of the Station Alpin du Lautaret of the University Joseph Fourier of Grenoble $\left(45^{\circ} 02^{\prime} \mathrm{N}\right.$ 
$6^{\circ} 24^{\prime} \mathrm{E}, 2100 \mathrm{~m}$ asl) in the French Alps (Fig. S1). In this site, both genuine snowbed species co-occur together with less specialised alpine meadow forbs.

Meteorological data were obtained from a nearby ( $<100 \mathrm{~m}$ distance) meteorological station in the Botanical Garden of the Station Alpin Joseph Fourier. Microclimatic data were additionally obtained with EL-USB-2-LCD sensors and data loggers (Lascar Electronics) placed $10 \mathrm{~cm}$ above ground (Fig S1A). Spectral irradiance was measured with a Maya 2000 Pro array spectroradiometer (Ocean Optics; D7-H-SMA cosine diffuser, Bentham Instruments Ltd.) recently calibrated to give faithful readings in the UV-visible regions of the solar spectrum. Measurements included dark and UV-filter calibrations to account for stray light in the UV region and noise in the baseline readings. To obtain maximum resolution in the UV regions, bracketing at $\times 10$ integration time was used for these spectral regions, following the protocols Aphalo et al. (2016) and Aphalo et al. (2017).

Five plant species were studied (Fig. 1); four of them are hemicryptophytes with perennial leaves (Soldanella alpina L., Homogyne alpina L., Geum montanum L. and Gentiana acaulis L.) and one, Crocus albiflorus Kit. ex Schult, is a geophyte producing new leaves in spring (Aeschimann et al. 2004). Among them, S. alpina belongs to the snowbed flora, H. alpina and G. montanum can be occasionally found in snowbeds but are typical alpine meadow species and $G$. acaulis and $C$. albiflorus are alpine meadow plants rarely found in snowbeds (Aeschimann et al. 2004). Thus, a gradation of strategies was evaluated during the study.

Physiological responses after snow melting were characterised across five spatial transects per species in small snow patches (mean and SD patch area 191 $\pm 41 \mathrm{~m}^{2}$ ). Around the snowbed, in the already melted area, samples were collected at three different distances from the edge (each transect represents a biological replicate): the first one in the melting edge, the second at $20 \mathrm{~cm}$ from the edge and the third 1-m away from the edge (Fig S1). Given the observed melting rate (approximately $15 \mathrm{~cm}$ per day), these relative distances from the edge are equivalent to approximately 1 day and 5-7 days without snow cover, respectively. Consequently, distances to the snow patch can be also interpreted in terms of "time after snowmelt". One to three leaves from each species were studied at each sampling point. Physiological measurements were carried out first (chlorophyll fluorescence, optically estimated flavonoid glycoside content and leaf transmittance spectra) and sampling for biochemical analyses were performed immediately after under a uniformly cloudy sky (PAR 288-707 $\mu$ mol photons $\mathrm{m}^{-2} \mathrm{~s}^{-1}$ ) and air temperatures ranging between +6.6 and $+11{ }^{\circ} \mathrm{C}$. Samples for biochemical analyses (approximately $40 \mathrm{~mm}^{2}$ leaf area) were collected per replicate, immediately frozen in liquid nitrogen and stored at $-80^{\circ} \mathrm{C}$ until extraction.

\section{2-Chlorophyll fluorescence}

Chlorophyll $a(\mathrm{Chl} a$ ) fluorescence was measured in the same five plants per species and measurement point as those used for biochemical analyses. Measurements were done between 11:00 and 15:00 using a portable modulated Plant Stress Kit fluorometer (Opti-Sciences). The operating quantum efficiency of PSII was measured by using the Opti-Sciences’ Y(II) meter. In intact illuminated leaves 
(i.e. directly exposed to natural solar radiation) the operating quantum efficiency of PSII was estimated as $\Delta F / F_{\mathrm{m}}{ }^{\prime}=\left(F_{\mathrm{m}}{ }^{\prime}-F_{\mathrm{s}}\right) / F_{\mathrm{m}}$ ', where $F_{\mathrm{m}}$ ' is the maximum Chl $a$ fluorescence induced with a saturating pulse and $F_{\mathrm{s}}$ is the actual $\mathrm{Chl} a$ fluorescence under illumination. Saturating pulses to calculate $F_{\mathrm{m}}$ ' values were applied according to Loriaux et al. (2013) protocol. The irradiance (PAR) was measured with the Leaf-Clip built-in quantum sensor and the electron transport rate (ETR) was estimated using the absorptance coefficient calculated for each leaf with the two RGB sensors placed in the measuring head. To allow inter-species comparisons, fluorescence measurements were performed during a uniformly cloudy afternoon under a narrow range of non-saturating irradiances: 382-473 $\mu \mathrm{mol}$ photons $\mathrm{m}^{-2} \mathrm{~s}^{-1}$ (Table S2). Immediately after $\Delta F / F_{\mathrm{m}}$ ' determinations, leaves were darkadapted with leaf clips (30 min) (Fig. S1b), the maximum Chl $a$ fluorescence $\left(F_{\mathrm{m}}\right)$ was induced with a saturating pulse ( $0.8 \mathrm{~s}$ duration, $7000 \mu \mathrm{mol}$ photons $\left.\mathrm{m}^{-2} \mathrm{~s}^{-1}\right)$ while the initial fluorescence $\left(F_{0}\right)$ was recorded with red modulated measuring light $\left(\mathrm{ML}<1 \mu \mathrm{mol}\right.$ photons $\left.\mathrm{m}^{-2} \mathrm{~s}^{-1}\right)$. The $F_{\mathrm{v}} / F_{\mathrm{m}}$ was then estimated by the ratio $F_{\mathrm{v}} / F_{\mathrm{m}}=\left(F_{\mathrm{m}}-F_{o}\right) / F_{\mathrm{m}}$.

\section{3-Flavonoid measurements}

Flavonoid glycoside (flavonols in dicots. and flavones in monocots.) and anthocyanin measurements of each leaf were made with a Dualex Scientific + (Force-A, Paris-Sud, France) immediately on sampling, directly following the Chl $a$ fluorescence measurements and prior to placing these leaves in liquid N. Both sides of each leaf were measured in the same region of the leaf lamina to obtain optical indices of flavonoid glycosides and anthocyanins from both the upper (adaxial) and lower (abaxial) epidermis. These optical indices are given by the Dualex from the abs. at $375 \mathrm{~nm}$ and $530 \mathrm{~nm}$, respectively, by comparison of $\mathrm{Chl} a$ fluorescence at each of these wavelengths based on the epidermal absorbance $375 \mathrm{~nm}$ (flavonoid glycosides) and $530 \mathrm{~nm}$ (anthocyanins) wavelengths, calculated by comparison of Chl $a$ fluorescence excited by these wavelengths and by red light. An index of leaf chlorophyll content per unit area is obtained concomitantly by the device using the light transmitted in the red and near-infrared regions. Taking measurements from both epidermises allowed us to calculate the upper/lower ratios of flavonoid glycoside and anthocyanin.

\section{4-Spectral measurements}

A leaf from each plant was placed in the Jaz Spectro-Clip (Ocean Optics), and reflectance was measured from the adaxial (upper) epidermis and transmittance through the leaves was measured beneath the abaxial (lower) epidermis using a coordinated dual spectrometer system. A xenon light source provides a pulse of light at a trigger rate of $10 \mathrm{~ms}$. Each leaf measurement comprised ten consecutive spectra recorded over a 4-min period, during which time there was no noticeable trend to suggest any short-term time-dependent variation in optical properties. The flash rate was set at $200 \mathrm{~Hz}$ with an intensity of $400 \mathrm{~V}$. Each leaf transmittance and reflectance spectra measured on a sample (S), were matched with a dark (D) and reference (Ref.) measurement using black and white Spectralon diffuse-reflectance reference targets (WS-1-SL, Ocean Optics). Spectral transmittance (T $\lambda$ ) and reflectance $(\mathrm{R} \lambda)$ were calculated according to Eq.1. 


$$
\operatorname{T} \lambda \text { or } R \lambda=\frac{S-D}{R e f .-D} * 100
$$

Spectral absorptance (A $\lambda$ ) was calculated as the proportion of emitted light remaining after subtracting that of $T \lambda$ and (R $\lambda)$. Post-processing of the raw spectra was done using the Photobiology suite of packages in R (Aphalo, 2015).

\section{5-Biochemical analyses}

Plant material was ground under liquid $\mathrm{N}_{2}$ and extracted with acetone (buffered with $0.5 \mathrm{~g} \mathrm{CaCO}_{3} \mathrm{~L}^{-1}$ ). The extracts were then centrifuged at $16100 \mathrm{~g}$ and $4{ }^{\circ} \mathrm{C}$ and pigment composition was analysed by HPLC using a reverse phase C18 column (Waters) as described previously (García-Plazaola et al. 1999) using a photodiode array detector (Waters model 996) for chlorophyll $a$ (Chl $a$ ), chlorophyll $b$ (Chl b), lutein (Lut), neoxanthin (Neo), $\beta$-carotene ( $\beta$-Car), violaxanthin (V), antheraxanthin (A) and zeaxanthin (Z) and a fluorescence detector (Waters model 474) for $\alpha$-tocopherol ( $\alpha$-toc) and plastochromanol-8 (PC8). Considering that carotenoid and lipophilic antioxidants are typically located in plastids, their concentrations were expressed as chlorophyll ratios.

\section{6-Statistical analyses}

One-way ANOVA with Tukey HSD test as post-hoc was conducted to evaluate significant differences among the positions 0, 20 and $100 \mathrm{~cm}$ from the snow edge for each species. Pearson correlation was used to evaluate the relationships among measured variables. All statistical analyses were conducted with SPSS 2019 (IBM Corp.) at an alpha level of 0.05.

\section{3-Results}

In 2019, the study period “Julian days 148-151" corresponded to snow retreat at the study site. During this period and the preceding week, the average temperature in the experimental field site was $+5.9^{\circ} \mathrm{C}$ with a maximum of $+13.6^{\circ} \mathrm{C}$ and a minimum of $-0.7^{\circ} \mathrm{C}$. The irradiance peak at solar noon during sunny days was over $2000 \mu \mathrm{mol}$ photons $\mathrm{m}^{-2} \mathrm{~s}^{-1}$ of photosynthetically active radiation (PAR), while the maximum unweighted ultraviolet-B radiation (UV-B: 280-315 nm) was more than $3.4 \mu \mathrm{mol}$ photons $\mathrm{m}^{-2} \mathrm{~s}^{-1}$. There was a large difference in irradiance between the snowpatch surface, which was c $10-15 \%$ higher due to reflected radiation from the surrounding snow, and that $100 \mathrm{~cm}$ away from the snowpatch (Fig. S2, Table S1). This is apparent in the different UV-B:PAR ratios between the irradiance on snow (2.06) and on the ground (1.71). The UV-B:PAR ratio is even higher in radiation reflected from the snowpatch (2.11 UV-B:PAR ratio), adding as much as $48 \%$ to the solar radiation (Table S1).

Apart from the physical effect on plants of the release from snow cover, environmental conditions also differed between the edge of the snowpatch and the points situated at 1-m distance (notice that distance to the snow is used as a proxy of time after melting) during the three days prior to the physiological measurements (Fig. S1d). In particular, at the snow-edge, the air temperature was up-to $5^{\circ} \mathrm{C}$ lower during daylight hours (particularly on sunny days) and the minimum temperature was 
slightly buffered compared to the 1-m point. Consequently, the extremes of the recorded temperatures during the study period were $-3.1^{\circ} \mathrm{C}$ (edge) and $-3.4^{\circ} \mathrm{C}(1 \mathrm{~m})$ for the minimum, and $+25.3^{\circ} \mathrm{C}$ (edge) and $+28.6^{\circ} \mathrm{C}(1 \mathrm{~m})$ for the maximum. No significant differences were found for PAR or $\mathrm{T}_{\text {leaf }}$ across species or sites (Table 1, Table S1).

The five species studied here represent a diversity of strategies but some general patterns were apparent. Thus, irrespective of strategy, maximal photochemical efficiency $\left(F_{\mathrm{v}} / F_{\mathrm{m}}\right)$ was relatively low in all species at the time of snow melting and did not rise significantly over the following days. On average, $F_{\mathrm{v}} / F_{\mathrm{m}}$ was $0.69-0.70$ in all species except for the sprouting leaves of $C$. albiflorus, which had values significantly lower than the rest of the species (Fig. 1, Table 1). In contrast to the lack of response of $F_{\mathrm{v}} / F_{\mathrm{m}}$, the actual photochemical efficiency $\left(\Delta F / F_{\mathrm{m}}\right.$ ') under ambient conditions increased rapidly in all species, except in $H$. alpina upon snow melting (Fig. 1). After one day, this increase was small in G. montanum, C. albiflorus and S. alpina but it sustained and was statistically significant after one week, while in $H$. alpina $\Delta F / F_{\mathrm{m}}$ ' increased after one day but decreased thereafter. The highest $\Delta F / F_{\mathrm{m}}$ ' values were obtained in $G$. montanum. Considering that $\Delta F / F_{\mathrm{m}}$ ' was measured at a relatively constant PAR, the electron transport rate (ETR) increased from 2 to 3-fold in all species except $H$. alpina (Fig. 1). The ETR was highest in G. montanum, but photochemistry was activated fastest following snowmelt in G. acaulis (3.5-fold rise from 0 to $100 \mathrm{~cm}$ from the snowpatch). It should be noted that leaf temperature during the measurements was slightly lower (on average $1.7-2.0^{\circ} \mathrm{C}$ ) at the snow edge (Table S2), except for C. albiflorus whose erect leaves were out of the snow influence.

In parallel with photochemical changes, pigment composition also varied in some of the studied species. Thus, Chl content increased by $56 \%$ in $S$. alpina, while the ratio of Chl $a / b$ decreased significantly in C. albiflorus, indicating a reorganisation of the photosynthetic apparatus (Fig. 2). The ratios of the main carotenoids (Lut, Neo and $\beta$-Car) to chlorophyll did not change significantly in any of the studied species, with the exception of a marked decrease in lutein (Fig. S3). Xanthophyll cycle (VAZ) ratio to Chl was much higher (3 to 4-fold) in expanding leaves of C. albiflorus than in the other species (Fig. 3). However, due to the rapid Chl synthesis, the VAZ/Chl ratio decreased markedly with leaf maturation, reaching values close to 2-fold higher in C. albiflorus than in the mature leaves of the other species. VAZ/Chl did not vary with the time after snowmelt in most other species, except for $G$. montanum, in which it increased by $80 \%$ (Fig. 3). Irrespective of VAZ pool size, the epoxidation state of the cycle $(A+Z) /(V+A+Z)$ did not change with time in any of the species studied (Fig. 3).

The pools of the main lipophilic antioxidants, $\alpha$-toc and PC8, varied greatly among species, being the lowest in C. albiflorus and the highest in G. acaulis (Fig. 4). When there were time-dependent variations after snowmelt, both antioxidants had a marked decline in C. albiflorus and G. acaulis. In G. montanum, the pattern of $\alpha$-toc was the opposite; it became enriched along the transect. The flavonoid glycoside content tended to increase with the time after snow melting, but this trend was only statistically significant for G. montanum (Fig. 4). Conversely, there was a non-significant trend towards a decrease in the anthocyanin content of all species but $H$. alpina. 
Generally, at the snowpack edge, leaf reflectance was higher and absorptance lower than at 1-m distance in both the UV and green parts of the spectrum, whereas reflectance was lower in the far-red (Fig. 5). Leaves of S. alpina showed the strongest trend for a change in leaf optical properties along the transect, although similar trends were also visible in G. montanum and G. aucalis (Fig. 5). The optical properties of H. alpina, in general, failed to differ along the transects. Between 320-800 nm, the spectral properties of leaves of each species were similar, although G. aucalis was notably more reflective than the others. At the extremes of the spectrum in the UV-B and near-infrared, species diverged from each other. Three of the species, apart from $G$. montanum, were more reflective in the UV-B region on initial emergence from under the snowpack than at 1-m distance (Fig. 5). These data can also be considered by comparing spectral regions. In Fig. S4 the differences in the red, far-red, green and in the UV regions can be easily visualised.

When all photoprotective parameters were considered together, a coordinated light acclimation response among photosynthetic pigments was apparent, with positive correlations between Lut/Chl, $\beta$ Car/Chl, VAZ/Chl and AZ/VAZ, and Chl a/b ratio (Fig. S5). On the other hand, flavonoid glycosides correlated negatively with other photoprotective parameters, including VAZ/Chl, AZ/VAZ, $\beta$-Car/Chl or Lut/Chl and also with Chl $a / b$ ratio (Fig. S5). A spider plot was used to illustrate a unified view of the suite of responses of all species (Fig. 6). It shows that the progressive activation of photochemistry and ETR represents the most prominent trend after the snowmelt along the transects (Fig. 6).

Apart from the time-dependent activation of protective attributes, there were significant differences amongst species (Table 1); the most pronounced being between C. albiflorus and the other species. In particular, the contents of lutein and VAZ were 2 to 3-fold higher in C. albiflorus (Table 1, Figs. 3 and S3). Conversely, its $\alpha$-toc and, to a lesser extent, PC8 were much lower than in the other species (Fig. 4). Despite having a similar Chl content to the other species, the ratio $C h l a / b$ was higher in $C$. albiflorus (Table 1). Carotenoid contents differed among most species, in particular in C. albiflorus (Table 1) that showed higher Lut and lower Neo than the others. The lipophilic antioxidants $\alpha$-toc and PC8 were higher in G. acaulis and S. alpina. Interestingly the rate of photoprotective response to snow melting was also species-dependent. G. montanum actively induced a rise in its xanthophyll cycle pool, tocopherol and adaxial flavonoid glycosides, while C. albiflorus followed the opposite pattern. Interestingly, PC8 content decreased in the less-specialised C. albiflorus, but was relatively constant in the intermediate species and accumulated in the most-specialised species, S. alpina (Figs. 4 and 6B). Overall, the photochemical activity of the facultative snowbed species G. acaulis and G. montanum recovered fastest under the field conditions in our study (Fig. 6B).

\section{4-Discussion}

\section{1-Trends in photoprotection with time after snowmelt}

In the present study, responses to snow melting were studied in five alpine plants representing a range of ecological strategies. Among these species, C. albiflorus was the only species producing new leaves 
from resting bulbs (Fig S1), while the others reactivated their photosynthesis in over-wintering leaves. The trade-offs between maintaining leaves through winter or remaining leafless under the snow have been well characterised in terms of carbon economy (Polgar and Primack 2011). Irrespective of the foliar strategy, the rapid activation of photosynthesis after snow melting is an essential attribute to assure fitness in highly competitive alpine environments (Hülber et al. 2011). Using the distance to the melting edge of the snow patch as a temporal marker, we have studied the photoprotective component of photosynthesis reactivation in several species with different degrees of adaptation to subnival life. Among them, S. alpina is considered to be a genuine snowbed species, with the capacity to maintain metabolic activities and growth at temperatures close to $0^{\circ} \mathrm{C}$ (Körner et al. 2019), while the others represent examples of alpine meadow species with different levels of adaptation to the stresses associated to long-lasting snow cover (Streb and Cornic 2012).

Irrespective of the time after snowmelt, all the studied species showed some degree of photoinhibition during daytime (e.g. $F_{\mathrm{v}} / F_{\mathrm{m}}$ values $<0.8$ ), although the extent of such a down-regulation in the PSII photochemical efficiency differed amongst species (Fig. 1), with the strongest down-regulation being found in the new leaves of C. albiflorus. Interestingly similar low values of $F_{\mathrm{v}} / F_{\mathrm{m}}$ were reported in mid-summer (not after emergence from snow) for S. alpina, H. alpina and G. montanum (Wildi and Lütz 1996; Streb et al. 1997), and for other montane species such as R. myconi (Fernández-Marín et al. $2020 \mathrm{~b}$ ), suggesting that intrinsically low values of $F_{\mathrm{v}} / F_{\mathrm{m}}$ could be a frequent trait of alpine plants. This low efficiency could be interpreted as a conservative strategy to reduce the risk of excess energy flow towards reactive oxygen species when carbon assimilation is restricted. The correlation between $F_{\mathrm{v}} / F_{\mathrm{m}}$ and VAZ/Chl or AZ/VAZ ratios was very weak (Fig S5), suggesting that this relationship is a constitutive characteristic not dynamically regulated by the operation of the xanthophyll cycle (Fig. 3 ) or by leaf chilling temperatures during the measurements (e.g. between 5 and $7^{\circ} \mathrm{C}$, Table 1 ) that occur in most cold-adapted plants (Míguez et al 2015).

One of the most consistent trends with the increasing time after melting was the activation of photochemical processes $\left(\triangle F / F_{\mathrm{m}}\right.$ ' and $\left.E T R\right)$ (Fig 1). Interestingly, this activation was neither related to changes in $F_{\mathrm{v}} / F_{\mathrm{m}}$ nor with enhanced de-epoxidation of the xanthophyll cycle (Figs 3 and S5). This indicates that the initial activation of photosynthesis (first week after snow melting) is independent of the complete recovery from winter photoinhibition or the operation of the xanthophyll cycle. The lower air temperature in the vicinity of the snow mass (Table S2) could be one of the factors limiting the photochemical activity in all species except $C$. albiflorus, whose leaves emerge vertically from the snow (Fig. S1C).

The activation of photochemistry was in general not accompanied by substantial changes in photoprotective traits, except in the expanding leaves of C. albiflorus where several compounds decreased in concentration (VAZ, $\alpha$-toc, PC8) (Figs. 3 and 4), and in the overwintering leaves of $G$. montanum where VAZ and $\alpha$-toc increased in parallel with ETR. It is interesting that VAZ and $\alpha$-toc pools correlated negatively with each other (Pearson correlation coefficient $=0.971, \mathrm{P}<0.05$, Fig. S5), 
suggesting a functional redundancy within the photosynthetic tissue, as has been described in Arabidopsis thaliana mutants (Havaux et al. 2005). In contrast to the pattern shown by antioxidant molecules in the present study (Fig. 4), it has been reported that the antioxidant enzymes of S. alpina increase their activity rapidly after snow melting (Streb et al. 1997) and that its foliar carotenoids and UV-absorbent flavonoids increase after the shade to sun transfer (Bidel et al. 2020). With the exception of $H$. alpina, passive filters such as anthocyanins and flavonoid glycosides in overwintering leaves also decreased after emerging from snow (Fig. 4) and this may be associated with the small drop in UV absorptance once the snow had melted. Arctic and alpine plants can start to accumulate flavonoid glycosides while still emerging from under the snowpack (Solanki et al., 2018), presumably driven by the combination of blue and UV radiation transmitted through the snow (Robson and Aphalo 2019) together with cold-temperature induction (Schultze and Bilger 2019). Consequently, virtually all the UV radiation that was not reflected was absorbed when the leaf was above the snow. However, this flavonoid glycoside accumulation may be reversed as warmth and irradiance temporarily decline with the reduced albedo associated with the transition from snow to vegetation cover, leading to less scattered and reflected radiation with distance from the snowpack (Fig. S2). These compounds could also be retained in overwintering leaves, as has been shown for flavonoids in leaves of S. alpina (Laureau et al 2015), enhancing photoprotection after snowmelt or playing other roles in the adaptation to subnival life. In particular, anthocyanins have a plethora of protective functions (Gould et al 2004; Sudheeran et al 2020), including antifungal and antimicrobial properties (Schaefer et al 2008), which could be of great value during the long period of snow cover.

\section{2-Species segregate in photoprotection according to over-wintering strategy}

The composition of photosynthetic pigments and tocochromanols in alpine forbs has scarcely been studied in detail in a couple of species. A study of plants growing at $2000 \mathrm{~m}$ a.s.l. in the Austrian Alps in late summer, found H. alpina to have slightly higher $\mathrm{Chl} a / b$ and VAZ/Chl ratios that than those we report here (Wildi and Lütz 1996). These slight differences could be explained by the high temperatures typical of mid-summer (July and August) (Wildi and Lütz 1996), compared to those at our study site in late spring. In a different study, it was reported that the antioxidant pool of $H$. alpina was half of the co-occurring S. alpina (Streb et al. 1997, 1998). The latter species, the only genuine snowbed plant in the present study (Körner et al. 2019), is characterised by a high degree of constitutive photoprotection (Streb et al. 2003) when compared to other alpine species. In this species, the pools of tocopherol reported in the literature (Streb et al. 1997, 1998, 2003, Wildi and Lütz 1996) are slightly lower than those measured in the present study, while VAZ pools were slightly higher. Again, the fact that those studies were performed at mid-summer, as opposed to late spring, could be indicative of seasonal trends in photoprotection. Besides, S. alpina was the only species to show significant changes in absorptance of visible light after its release from snow cover (Fig. S4), likely caused by structural rearrangements (Davis et al. 2011). Chlorophyll biosynthesis was also noticeable, 
with a two-fold increase in just one week. Interestingly, a sister species (S. pusilla) is known to be metabolically active at $0^{\circ} \mathrm{C}$ and to initiate the development of new tissues under such conditions (Körner et al. 2019).

C. albiflorus had the most distinct strategy. Amongst the five species, it had the highest photoinhibition (Fig. 1), the highest Chl a/b, Lut/Chl, VAZ/Chl and AZ/VAZ ratios (Fig. 2, 3 and S3), and the lowest $\alpha$-toc content (Fig. 4). The distinct response of C. albiflorus may derive from the new and vertical leaves that emerge from the melting snow (Fig. S1C), whereas all other species already had mature perennial leaves under the snow. Young greening tissues are particularly sensitive to harsh alpine conditions until they reach maturity, as has been shown in Eriophorum angustifolium (Lütz 1996). In our study, C. albiflorus had a higher Chl $a / b$ ratio than all the other species. The lower Chl $a / b$ ratio of these species could indicate that they have more antennae proteins per unit of reaction centre, which would favour light harvesting under the snow or on cloudy days (Esteban et al. 2015). Interestingly, C. albiflorus was apparently able to compensate for the low $\alpha$-toc values typical of young leaves (Hormaetxe et al. 2004, Lizarazo et al. 2010) by maintaining a high VAZ pool. Its leaf VAZ/Chl values, particularly close to the edge of the snow patch (around $250 \mu \mathrm{mol} \mathrm{mol}^{-1} \mathrm{Chl}$ ), were clearly above what is typical for boreoalpine species (100 mmol mol ${ }^{-1} \mathrm{Chl}$ on average) (FernándezMarín et al. 2018, 2019, 2020a). On the other hand, wintergreen species compensated for the risk of overexcitation of photosynthetic apparatus with higher $\alpha$-toc, PC-8 and flavonoid glycoside contents than C. albiflorus (Fig. 4). Together, this suite of responses suggests a functional trade-off or a switch in strategies between responses that may occur in other time frames.

\section{5-Concluding remarks}

In alpine ecosystems, snowmelt marks the onset of growth and the race for plants to complete their annual life cycle within the short growing season. When considering long-lasting snow patches, the inception of growth is postponed to late spring or early summer when plants potentially receive very high intensities of solar radiation. Consequently, when overwintering or new expanding leaves are starting to re-activate photosynthesis, they may also suddenly be exposed to the strong UV radiation and PAR that are amongst the highest on Earth, in combination with temperatures that, because of the proximity of the snowpack, often remain relatively low. This cocktail of environmental stress factors represents an extreme environment for plants, meaning photoprotection mechanisms play a pivotal role in guaranteeing that photosynthesis can be readily activated after snowmelt. While the results obtained here do not indicate a distinctive photoprotective strategy for species adapted to subnival life, we have found important interspecific differences. Whatever the photoprotection strategy, alterations in the date of spring snow melting caused by climate warming will undoubtedly affect the importance of such mechanisms and their contribution to the overall plant success. It is likely that this will alter the ecological relationships among species, with the more specialized snowbed species being displaced by more plastic alpine meadow forbs. 


\section{Author contributions}

J.I.G-P., B.F-M, and T.M.R. designed the study. J.I.G-P., B.F-M, T.S. and T.M.R. performed the field measurements. J.I.G-P. and A.S. performed the laboratory measurements. J.I.G-P., B.F-M, and T.M.R. discussed the results and wrote the manuscript.

Acknowledgements - The Spanish Ministry of Science, Innovation and Universities (MICIU/FEDER, EU) and the Basque Government funded this research through the projects PGC2018-093824-B-C44 and UPV/EHU IT-1018-16. The field campaign was partially funded by a grant to TMR from EU Horizon 2020 European Long-Term Ecosystem and Socio-Ecological Research Infrastructure Transnational-Access Scheme (EU H2020 eLTER TA), of which the Station Alpin Joseph Fourier, Lautaret Garden-UMS 3370 is a member (Univ. Grenoble Alpes, CNRS, SAJF, LTSER Zone Atelier Alpes, 38000 Grenoble, France).

\section{Data availability statement}

The data that support the findings of this study are available from the corresponding author upon reasonable request

\section{References}

Aeschimann D, Lauber K, Moser DM, Theurillat JP (2004) Flora alpina, Belin, Paris

Aphalo PJ (2015) The r4photobiology suite: spectral irradiance. UV4Plants Bulletin 1: 19-27

Aphalo PJ (2017) Quantification of UV Radiation. In: BR Jordan (ed) UV-B Radiation and Plant Life: Molecular Biology to Ecology, CABI International, Oxford, pp 10-22

Aphalo PJ, Robson TM, Piiparinen J (2016) How to check an array spectrometer [Online]. Available at http://uv4plants.org/methods/how-to-check-an-array-spectrometer/ (accessed 1 October 2020)

Bannister P, Maegli T, Dickinson K, Halloy S, Knight A, Lord J, Mark AF, Spencer K (2005) Will loss of snow cover during climatic warming expose New Zealand alpine plants to increased frost damage? Oecologia 144: 245-256

Bascuñán-Godoy L, García-Plazaola JI, Bravo LA, Corcuera LJ (2010) Leaf functional and micromorphological photoprotective attributes in two ecotypes of Colobanthus quitensis from the Andes and Maritime Antarctic. Polar Biol 33: 885-896

Bidel LPR, Meyer S, Talhouët A, Baudin X, Daniel C, Cazals G, Streb P (2020) Epidermal UVA screening capacity measured in situ as an indicator of light acclimation state of leaves of a very plastic alpine plant Soldanella alpina L. Plant Physiol Biochem 151: 10-20

Björk RG, Molau U (2007) Ecology of Alpine Snowbeds and the Impact of Global Change. Arct Antarct Alp Res 39: 34-43

Blumthaler M (2012) Solar radiation in the high Alps. In: Lütz C (ed) Plants in Alpine Regions, 
Springer-Verlag/Wien, pp 11-20

Briceño V, Harris-Pascal D, Nicotra A, Williams E, Ball M (2014) Variation in snow cover drives differences in frost resistance in seedlings of the alpine herb Aciphylla glacialis. Environ Exp Bot 106: 174-181

Carbognani M, Tomaselli M, Petraglia A (2014) Current vegetation changes in an alpine late snowbed community in the south-eastern Alps (Italy). Alp Bot 124: 105-113

Davis PA, Caylor S, Whippo CW, Hangarter RP (2011) Changes in leaf optical properties associated with light-dependent chloroplast movements. Plant Cell Environ 34: 2047-2059

Esteban R, Barrutia O, Artetxe U, Fernández-Marín B, Hernández A, García-Plazaola JI (2015) Internal and external factors affecting photosynthetic pigment composition in plants: a meta-analytical approach. New Phytol 206: 268-280

Fernández-Marín B, Atherton J, Olascoaga B, Kolari P, Porcar-Castell A, García-Plazaola JI (2018) When the sun never sets: daily changes in pigment composition in three subarctic woody plants during the summer solstice. Trees-Struct Funct 32: 615-630

Fernández-Marín B, Gago J, Flexas J, Gulías J (2019) Plant pigment cycles in the high-Arctic Spitsbergen. Polar Biol 42: 675-684

Fernández-Marín B, Gulías J, Figueroa CM, Iñiguez C, Clemente-Moreno MJ, Nunes-Nesi A, Fernie AR, Cavieres LA, Bravo LA, García-Plazaola JI, Gago J (2020a) How do vascular plants perform photosynthesis in extreme environments? An integrative ecophysiological and biochemical story. Plant J 101: 979-1000

Fernández-Marin B, Nadal M, Gago X, Fernie AR, López-Pozo M, Artetxe U, García-Plazaola JI, Verhoeven A (2020b) Born to revive: Molecular and physiological mechanisms of double tolerance in a paleotropical and resurrection plant. New Phytol 226: 741-759

García-Plazaola JI, Becerril JM (1999) A rapid HPLC method to measure lipophilic antioxidants in stressed plants: simultaneous determination of carotenoids and tocopherols. Phytochem Anal 10: 307313

Germino MJ, Smith WK (2000) High resistance to low-temperature photoinhibition in two alpine, snowbank species. Physiol Plant 110: 89-95

Gobiet A, Kotlarski S, Beniston M, Heinrich G, Rajczak J, Stoffel M (2014) 21 $1^{\text {st }}$ century climate change in the European Alps-A review. Scie Total Environ 493: 1138-1151

Gould KS (2004) Nature's Swiss army knife: the diverse protective roles of anthocyanins in leaves. J Biomed Biotechnol 2004:5 314-320

Gritsch A, Dirnbock T, Dullinger S (2016) Recent changes in alpine vegetation differ among plant communities. J Veg Sci 27: 1177-1186

Havaux M, Eymery F, Porfirova S, Rey P, Dörmann P (2005) Vitamin E protects against photoinhibition and photooxidative stress in Arabidopsis thaliana. Plant Cell 17: 3451-3469

Hormaetxe K, Hernández A, Becerril JM, García-Plazaola JI (2004) Role of red carotenoids in 
photoprotection during winter acclimation in Buxus sempervirens leaves. Plant Biol 6: 325-332

Hülber K, Bardy K, Dullinger S (2011) Effects of snowmelt timing and competition on the performance of alpine snowbed plants. Perspect Plant Ecol 13: 15-26

Huner NPA, Öquist G, Sarhan F (1998) Energy balance and acclimation to light and cold. Trends Plant Sci 3: 224-230

Komac B, Pladevall C, Peñuelas J, Conesa JV, Domènech M (2015) Variations in functional diversity in snowbed plant communities determining snowbed continuity. Plant Ecol 216: 1257-1274

Körner C (2003) Alpine plant life. Functional Plant Ecology of High Mountain Ecosystems, $2^{\text {nd }}$ Edn. Springer-Verlag, Berlin-Heidelberg

Körner C, Riedl S, Keplinger T, Richter A, Wiesenbauer J, Schweingruber, Hiltbrunner E (2019) Life at $0{ }^{\circ} \mathrm{C}$ : the biology of the alpine snowbed plant Soldanella pusilla. Alp Bot 129: 63-80

Laureau C, Paepe RDE, Latouche G, Moreno-chacón M, Finazzi G, Kuntz M, Cornic G, Streb P (2013) Plastid terminal oxidase (PTOX) has the potential to act as a safety valve for excess excitation energy in the alpine plant species Ranunculus glacialis L . Plant Cell Environ 36: 1296-1310

Laureau C, Meyer S, Baudin X, Huignard C, Streb P (2015) In vivo epidermal UV-A absorbance is induced by sunlight and protects Soldanella alpine leaves from photoinhibition. Funct Plant Biol 42: 599-608

Lizarazo K, Fernández-Marín B, Becerril JM, García-Plazaola JI (2010) Ageing and irradiance enhance vitamin E content in green edible tissues from crop plants. J Sci Food Agric 90: 1994-1999

Loriaux SD, Avenson TJ, Welles JM; Mcdermitt DK, Eckles RD, Riensche B, Genty B (2013) Closing in on maximum yield of chlorophyll fluorescence using a single multiphase flash of subsaturating intensity. Plant Cell Environ 36: 1755-1770

Leuschner C, Ellenberg H (2017) Ecology of Central European Non-Forest Vegetation:Coastal to Alpine, Natural to Man-Made Habitats, Springer International Publishing, Switzerland

Lütz C (1996) Avoidance of Photoinhibition and Examples of Photodestruction in High Alpine Eriophorum. J Plant Physiol 148: 120-128

Lütz C (2010) Cell physiology of plants growing in cold environments. Protoplasma 244: 53-73

Manuel N, Cornic G, Aubert S, Choler P, Bligny R, Heber U (1999) Protection against photoinhibition in the alpine plant Geum montanum. Oecologia 119: 149-158

Matteodo M, Ammann K, Verrecchia EP, Vittoz P (2016) Snowbeds are more affected than other subalpine-alpine plant communities by climate change in the Swiss Alps. Ecol Evol 6: 6969-6982 Míguez F, Fernández-Marín B, Becerril JM, García-Plazaola JI (2015) Activation of photoprotective winter photoinhibition in plants from different environments: A literature compilation and metaanalysis. Physiol Plant 155: 414-423

Moser T, Holzinger A, Buchner O (2015) Chloroplast protrusions in leaves of Ranunculus glacialis L respond significantly to different ambient conditions, but are not related to temperature stress. Plant Cell Environ 38: 1347-1356 
Ninot JM, Grau O, Carrillo E, Guàrdia R, Lluent A, Illa E (2013) Functional Plant Traits and Species Assemblage in Pyrenean Snowbeds. Folia Geobot 48: 23-38

Pickering C, Green K, Barros AA, Venn S (2014) A resurvey of late-lying snowpatches reveals changes in both species and functional composition across snowmelt zones. Alp Bot 124: 93-103

Polgar CA, Primack RB (2011) Leaf-out phenology of temperate woody plants: from trees to ecosystems. New Phytol 191: 926-941

Robson TM, Aphalo PJ (2019) Transmission of ultraviolet, visible and near-infrared solar radiation to plants within a seasonal snow pack. Photochem Photobiol Sci 18: 1963-1971

Schaefer HM, Rentzsch M, Breuer M (2008) Anthocyanins reduce fungal growth in fruits. Nat Prod Commun 8: 1267-1272

Schultze M, Bilger W (2019) Acclimation of Arabidopsis thaliana to low temperature protects against damage of photosystem II caused by exposure to UV-B radiation at $9^{\circ} \mathrm{C}$. Plant Physiol Biochem 134: 73-80.

Schöb C (2010) The sensitivity of plant interactions and species distribution in alpine snowbeds to climate change. Ecosistemas 19: 161-164

Sellaro R, Crepy M, Trupkin SA, Karayekov E, Buchovsky AS, Rossi C, Casal JJ (2010) Cryptochrome as a sensor of the blue/green ratio of natural radiation in Arabidopsis. Plant Physiol 154: 401-409

Solanki T, Aphalo PJ, Neimane S, Hartikainen SM, Pieristè M, Shapiguzov A, Porcar-Castell JA, Atherton J, Heikkilä A, Robson TM (2019) UV-screening and springtime recovery of photosynthetic capacity in leaves of Vaccinium vitis-idaea above and below the snow pack. Plant Physiol Biochem 134: 40-52

Starr G, Oberbauer SF (2003) Photosynthesis of Arctic evergreens under snow: implication for tundra ecosystem carbon balance. Ecology 84: 1415-1420

Streb P, Cornic G (2012) Photosynthesis and antioxidative protection in alpine herbs. In: Lütz C (ed) Plants in Alpine Regions, Springer-Verlag/Wien, pp 75-97

Streb P, Feierabend J, Bligny R (1997) Resistance to photoinhibition of photosystem II and catalase and antioxidative protection in high mountain plants. Plant Cell Environ 20: 1030-1040

Streb P, Shang W, Feierabend J, Bligny R (1998) Divergent strategies of photoprotection in highmountain plants. Planta 207: 313-324

Streb P, Aubert S, Bligny R (2003) High Temperature Effects on Light Sensitivity in the Two High Mountain Plant Species Soldanella alpina (L.) and Rannunculus glacialis (L.). Plant Biol 5: 432-440 Sudheeran PK, Ovadia R, Galsarker O, Maoz I, Sela N, Maurer D, Feygenberg O, Shamir MO, Alkan N (2020) Glycosylated flavonoids: fruit’s concealed antifungal arsenal. New Phytol 225: 1788-1798 Takahashi S, Badger MR (2011) Photoprotection in plants: a new light on photosynthetic II damage. Trends Plant Sci 16: 53-60

Tonin R, Gerdoi R, Tomaselli M, Petraglia A, Carbognani M, Wellstein C (2019) Intraspecific 
functional trait response to advanced snowmelt suggests increase of growth potential but decrease of seed production in snowbed plant species. Front Plant Sci 10-289

Verhoeven A (2013) Sustained energy dissipation in winter evergreens. New Phytol 201: 57-65

Wheeler JA, Hoch G, Cortés AJ, Sedlacek J, Wipf S, Rixen C (2014) Increased spring freezing vulnerability for alpine shrubs under early snowmelt. Oecologia 175: 219-229

Wildi B, Lütz C (1996) Antioxidant composition of selected high alpine plant species from different altitudes. Plant Cell Environ 19: 138-146

\section{Supporting information}

Additional supporting information may be found online in the supporting information section at the end of the article:

Fig. S1. Experimental site and environmental conditions during the field campaign.

Fig. S2. Spectral photon irradiance at the experimental site.

Fig. S3. Carotenoid ( $\beta$-carotene, lutein and neoxanthin) ratios to chlorophyll.

Fig. S4. Mean optical properties of leaves (reflectance and absorptance) of each of the four species studied in several spectral regions.

Fig. S5. Pearson correlation matrix of the main parameters measured across all species and sampling sites.

Table S1. Spectral photon irradiances in two locations and its supplementation by radiation reflected by snow were calculated from the spectra reproduced in Fig S2.

Table S2. Leaf temperature $\left(\mathrm{T}_{\text {leaf, }}\right.$ in $\left.{ }^{\circ} \mathrm{C}\right)$, PAR $\left(\mu \mathrm{mol} \mathrm{m}{ }^{-2} \mathrm{~s}^{-1}\right)$ and electron transport rate $\left(\mu \mathrm{mol} \mathrm{e}^{-} \mathrm{m}^{-2} \mathrm{~s}^{-}\right.$ ${ }^{1}$ ) during measurements of chlorophyll fluorescence.

\section{Figure legends:}

Fig. 1. Photochemical parameters $\left(F_{\mathrm{v}} / F_{\mathrm{m}}, \Delta F_{\mathrm{v}} / F_{\mathrm{m}}\right.$ ' and Electron Transport Rate) in leaves of the five species studied along transects at three distances $(0,20$ and $100 \mathrm{~cm})$ from the edge of the snow patches. Boxes represent the interquartile range of the data, the central line represents the median and whiskers the minimum and maximum range excluding outliers. Letters denote significant differences $(P<0.05$, one-way ANOVA and Tukey's posthoc test, $n=5)$ among positions along the transect. Upper panels show images of the flowers of the respective species. The colour code for each species is based on flower colours.

Fig. 2. Chlorophyll content (in $\mu \mathrm{mol} \mathrm{m}^{-2}$ leaf area) in leaves of the five species studied at three distances $(0,20$ and $100 \mathrm{~cm})$ from the edge of the snow patches. Boxes represent the interquartile range of the data, the central line represents the median and whiskers the minimum and maximum range excluding outliers. Letters denote significant differences $(P<0.05$, one-way ANOVA and Tukey's posthoc test, $n=5$ ) among positions in the transect from the snow patches.

Fig. 3. VAZ ratio to chlorophyll (in mmol $\mathrm{mol}^{-1} \mathrm{Chl}$ ) and de-epoxidation index $(\mathrm{A}+\mathrm{Z}) /(\mathrm{V}+\mathrm{A}+\mathrm{Z})$ in 
leaves of the five species studied at three distances $(0,20$ and $100 \mathrm{~cm})$ from the edge of the snow patches. Boxes represent the interquartile range of the data, the central line represents the median and whiskers the minimum and maximum range excluding outliers. Letters denote significant differences $(P<0.05$, one-way ANOVA and Tukey's posthoc test, $n=5)$ among positions in the transect from the snow patches.

Fig. 4. $\alpha$-tocopherol and plastochromanol-8 ratios to chlorophyll (in mmol mol${ }^{-1} \mathrm{Chl}$ ) and flavonoid glycoside and anthocyanin contents (in arbitrary units) in leaves of the five species studied at three distances $(0,20$ and $100 \mathrm{~cm}$ ) from the edge of the snow patches. Due to the morphological structure of C. albiflorus leaves accurate measurements of anthocyanins were not possible. Boxes represent the interquartile range of the data, the central line represents the median and whiskers the minimum and maximum range excluding outliers. Letters denote significant differences $(P<0.05$, one-way ANOVA and Tukey’s posthoc test, $\mathrm{n}=5$ ) among positions in the transect from the snow patches.

Fig. 5. The optical properties of leaves of four of the five species studied: C. albiflorus leaves were to narrow and ribbed to be measured. Each spectrum was plotted at $0.5 \mathrm{~nm}$ resolution between 290-880$\mathrm{nm}$ wavelength, as bands representing +/- $1 \mathrm{SE}$ centred around the mean from five replicate transects. Values are the proportion of incident irradiance reflected and absorbed by leaves as measured by the Jaz Spectro-Clip.

Fig. 6. Spider plot providing a unified view of trends in photochemistry, photoprotection and leaf environment (A) along the transect and (B) across species. Panel (A) depicts the fold-change for every parameter when compared to the edge of the snow patch $(0 \mathrm{~cm})$, thus values around 1 denote no change, $<1$ denote decrease and $>1$ denote rise upon snow melting. All species were considered together. Panel (B) depicts the fold-change for every parameter when comparing values at $100 \mathrm{~cm}$ with values at $0 \mathrm{~cm}$ for each species individually. Thus, values $<1$ denote decrease and $>1$ rise upon snow melting.

Table 1. Species average values (all measurements pooled) for pigment and tocochromanols, adaxial flavonoid glycosides and leaf temperature $\left({ }^{\circ} \mathrm{C}\right)$ during the measurements. Total chlorophyll content is

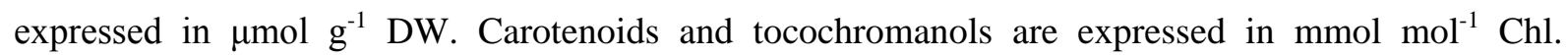
Flavonoid glycosides are relative units. Data are average \pm SE. When significant, differences amongst species are depicted with lowercase letters $(\mathrm{P}<0.05$, one-way ANOVA and Tukey's posthoc test, $\mathrm{n}=15)$. 


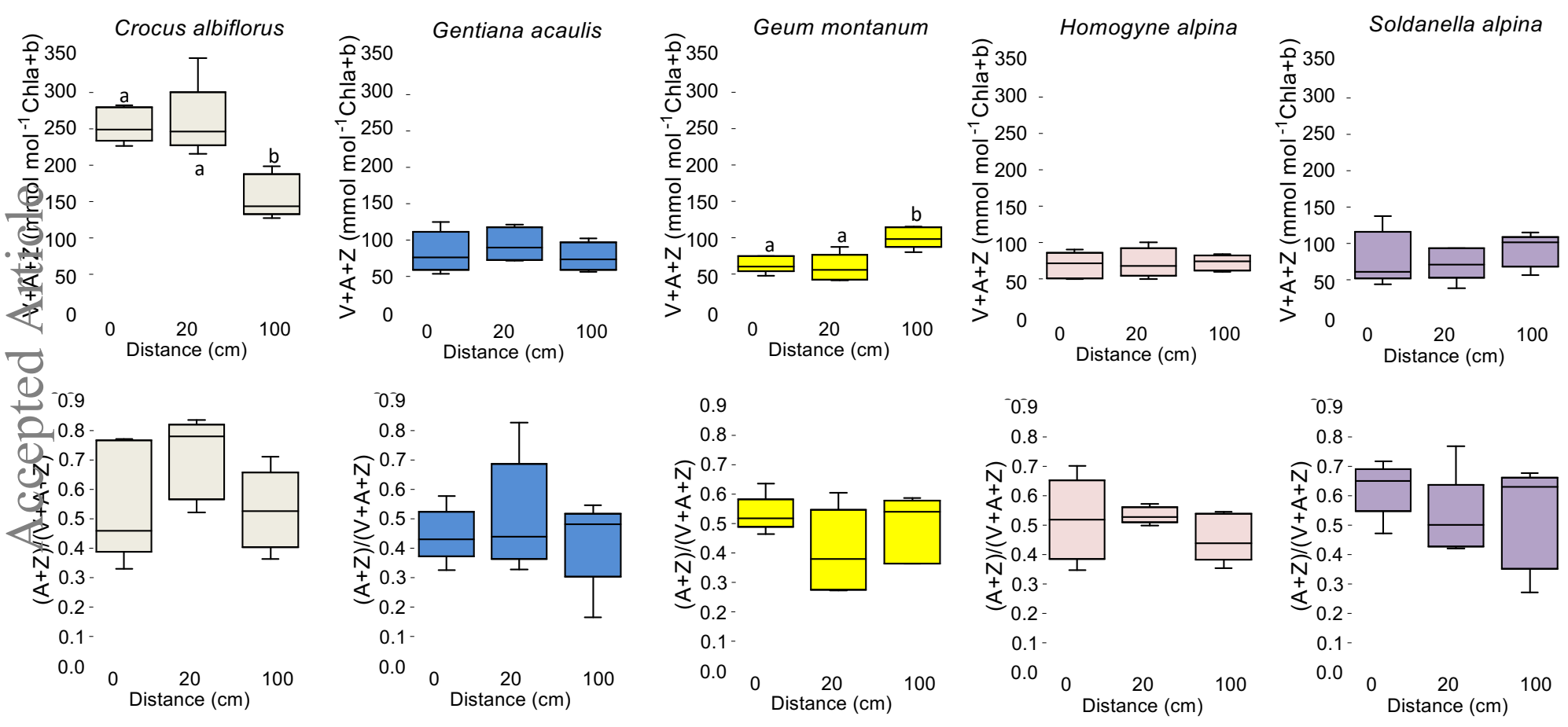


Gentiana acaulis
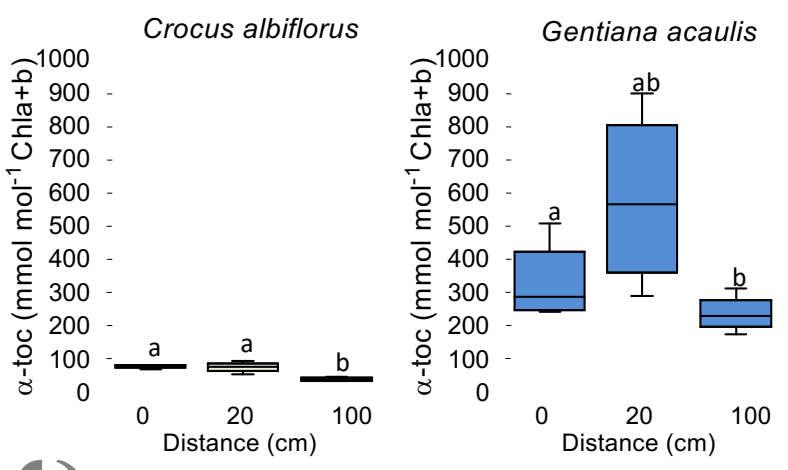

Geum montanum
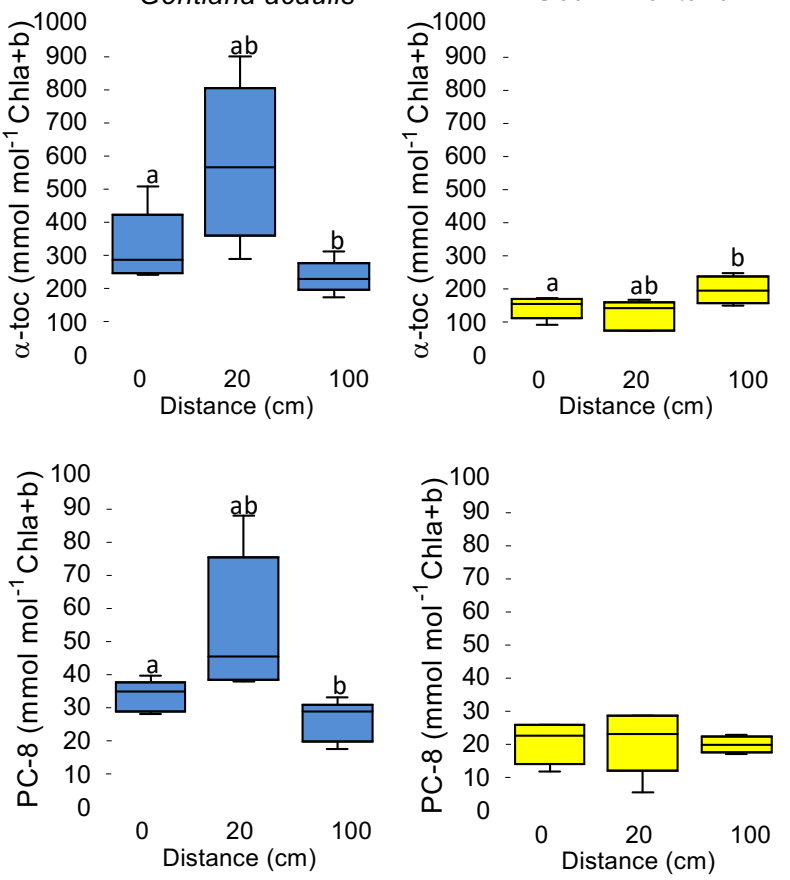

2.5

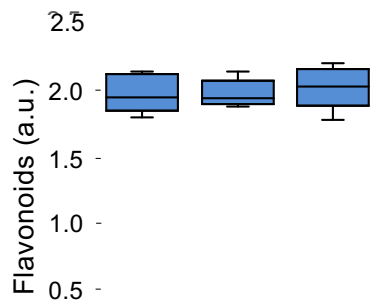

$0 \underset{\text { Distance }(\mathrm{cm})}{20} 100$

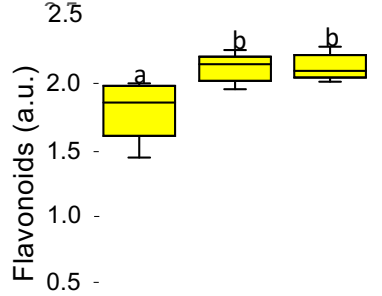

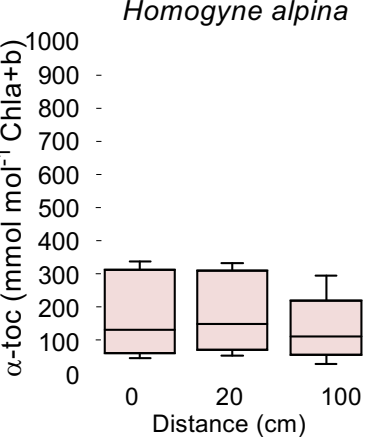
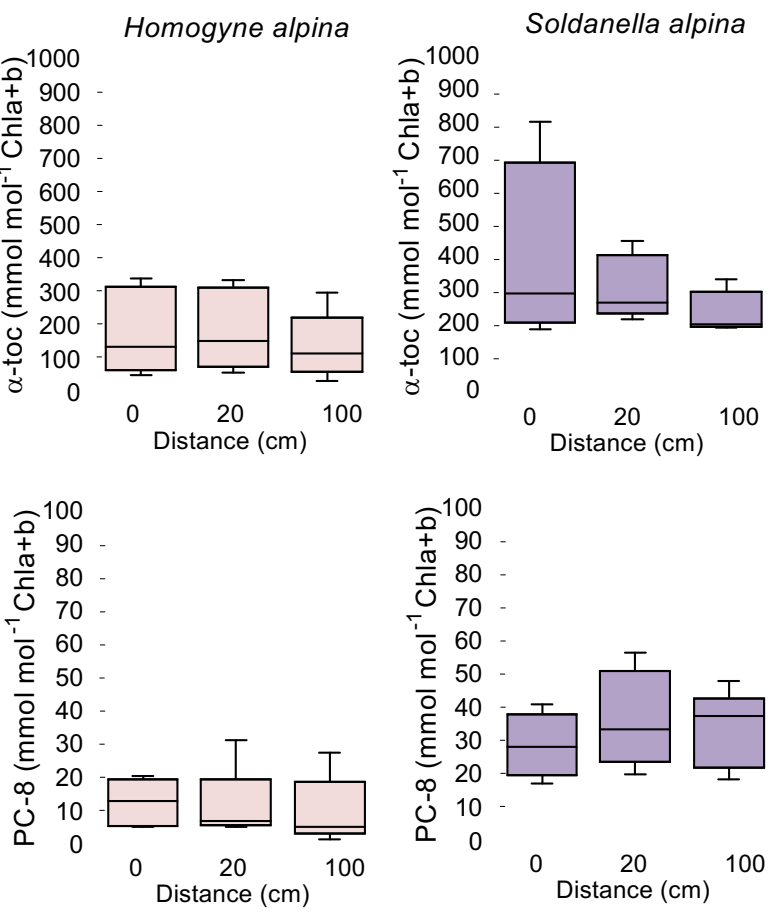

2.5
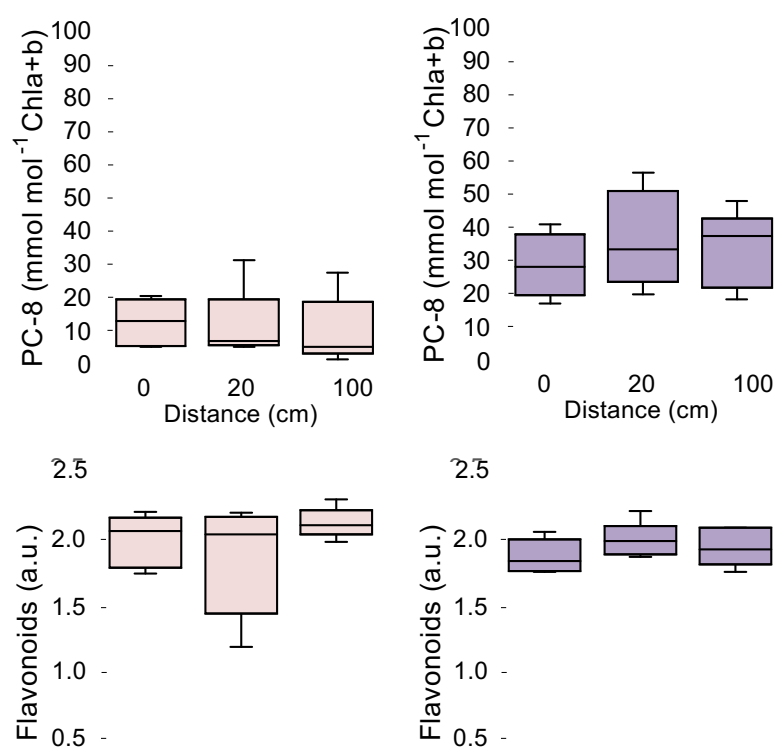

\section{5}

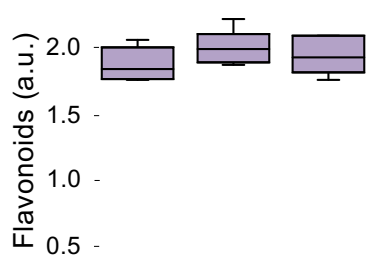

0.0
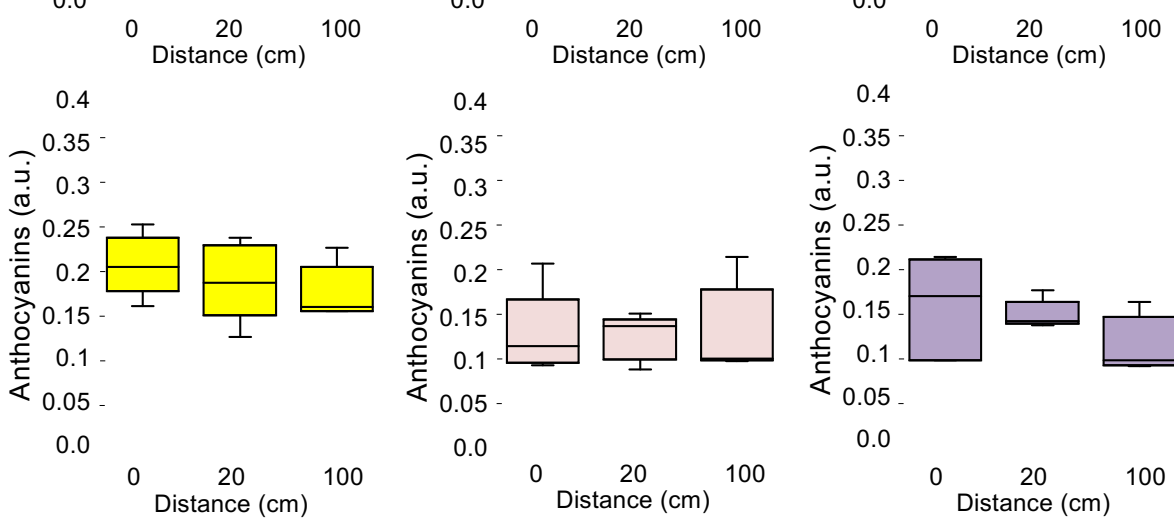

0.4

ذँ 0.3 -

(क) 0.25 -

(5) 0.25

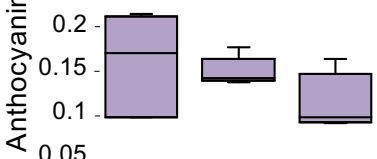

0.0

$0 \begin{gathered}20 \\ \text { Distance (cm) }\end{gathered}$ 


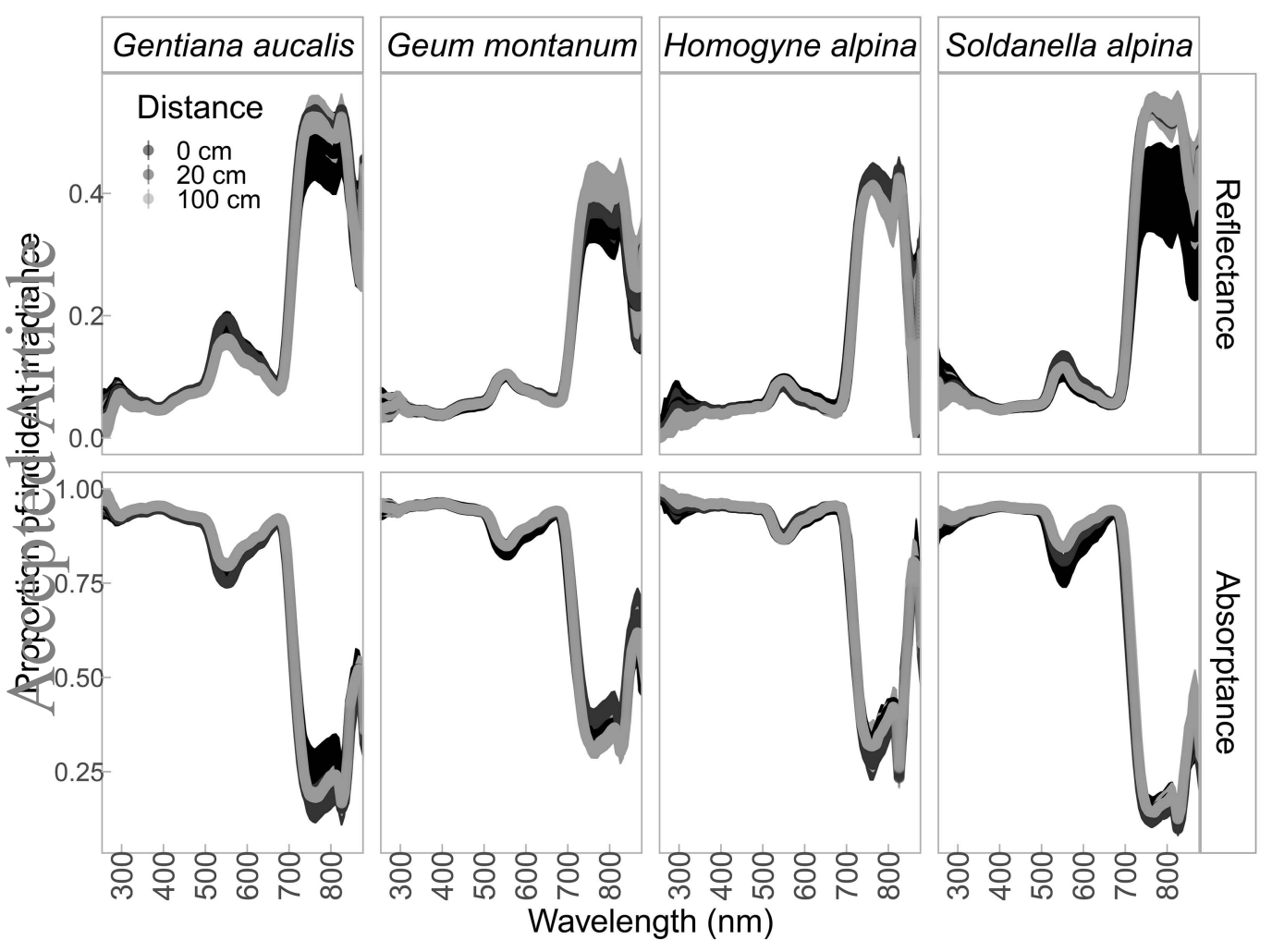




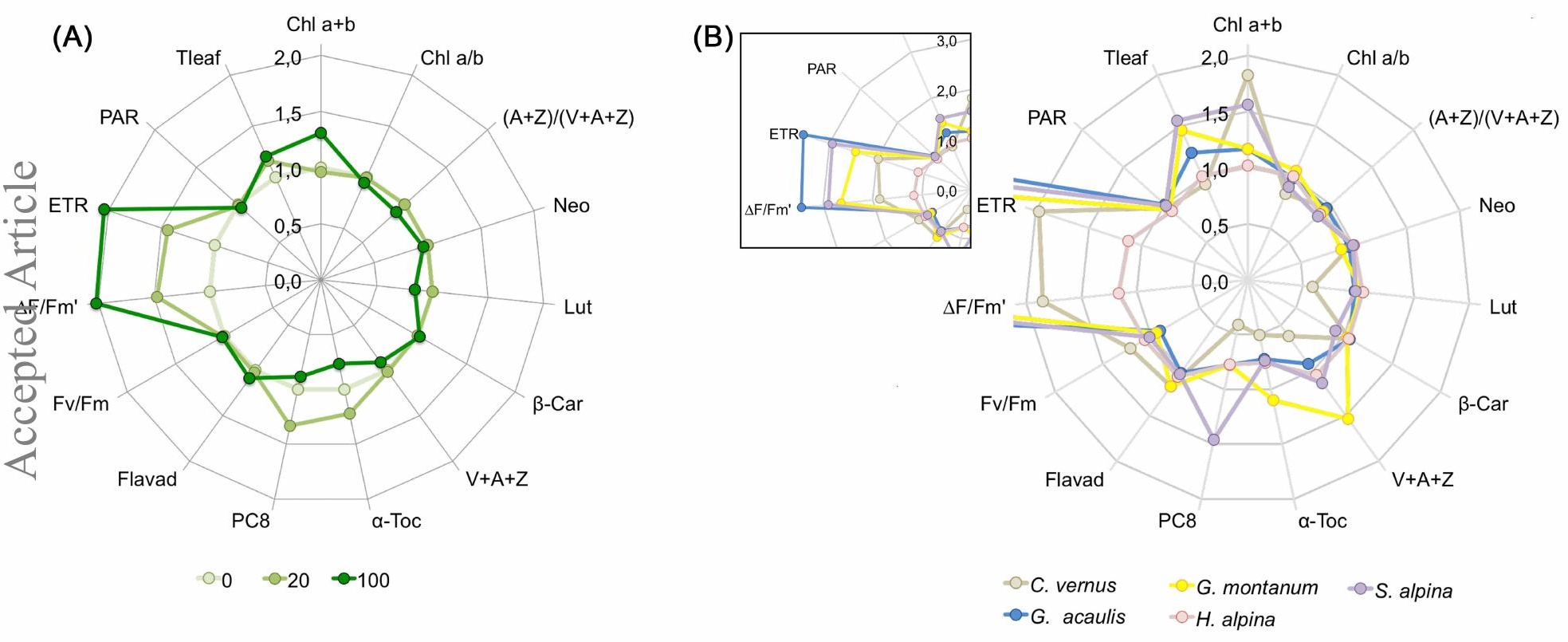




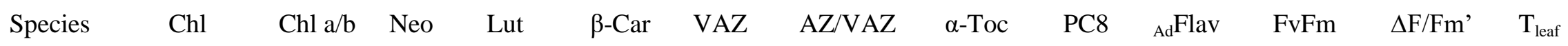
$\mathrm{a}+\mathrm{b}$

\begin{tabular}{|c|c|c|c|c|c|c|c|c|c|c|c|c|c|c|c|}
\hline $\begin{array}{l}\text { Crocus } \\
\text { albiflorus }\end{array}$ & $\begin{array}{l}274 \pm \\
45 \mathrm{ab}\end{array}$ & $\begin{array}{l}3.7 \\
0.1 \mathrm{a}\end{array}=$ & $\begin{array}{l}38 \pm 1 \\
d\end{array}$ & $\begin{array}{l}323 \pm \\
23 \mathrm{a}\end{array}$ & $\begin{array}{l}103 \pm \\
2 \mathrm{a}\end{array}$ & $\begin{array}{ll}223 & \pm \\
15 \mathrm{a} & \end{array}$ & $\begin{array}{l}0.588 \\
0.044 \text { a }\end{array}$ & \pm & 5 & & $\begin{array}{l}10 \pm \\
1 \mathrm{~b}\end{array}$ & $\begin{array}{l}1.22 \quad \pm \\
0.06 \mathrm{~b}\end{array}$ & $\begin{array}{l}0.57 \quad \pm \\
0.02 \mathrm{a}\end{array}$ & $\begin{array}{l}0.32 \\
0.03 \mathrm{a}\end{array}$ & $\begin{array}{l}=6.5 \\
0.4\end{array}$ \\
\hline $\begin{array}{l}\text { Gentiana } \\
\text { acaulis }\end{array}$ & $\begin{array}{ll}244 & \pm \\
22 \mathrm{~b} & \end{array}$ & $\begin{array}{l}2.6 \\
0.0 \mathrm{~b}\end{array}$ & $\begin{array}{l}44 \pm 1 \\
c\end{array}$ & $\begin{array}{l}184 \pm \\
8 \mathrm{~b}\end{array}$ & $\begin{array}{l}93 \pm 2 \\
c\end{array}$ & $\begin{array}{l}84 \pm 6 \\
b\end{array}$ & $\begin{array}{l}0.447 \\
0.038 \mathrm{~b}\end{array}$ & \pm & $\begin{array}{l}377 \\
53 \mathrm{a}\end{array}$ & & $\begin{array}{l}38 \pm \\
4 \mathrm{a}\end{array}$ & $\begin{array}{l}1.97 \pm \\
0.03 \mathrm{a}\end{array}$ & $\begin{array}{l}0.65 \quad \pm \\
0.02 \mathrm{~b}\end{array}$ & $\begin{array}{l}0.12 \\
0.03 \mathrm{~b}\end{array}$ & $\begin{array}{l}7.1 \\
0.6\end{array}$ \\
\hline $\begin{array}{l}\text { Geum } \\
\text { montanum }\end{array}$ & $\begin{array}{l}304 \pm \\
14 \mathrm{ab}\end{array}$ & $\begin{array}{l}2.7 \\
0.0 \mathrm{~b}\end{array}$ & $\begin{array}{l}50 \pm 1 \\
a b\end{array}$ & $\begin{array}{l}152 \pm \\
3 \mathrm{~b}\end{array}$ & $\begin{array}{l}98 \pm 1 \\
a b c\end{array}$ & $\begin{array}{l}77 \pm 6 \\
b\end{array}$ & $\begin{array}{l}0.466 \\
0.030 \mathrm{ab}\end{array}$ & \pm & $\begin{array}{l}149 \\
12 \mathrm{c}\end{array}$ & & $\begin{array}{l}20 \pm \\
2 b\end{array}$ & $\begin{array}{l}1.97 \pm \\
0.05 \mathrm{a}\end{array}$ & $\begin{array}{l}0.70 \quad \pm \\
0.01 \mathrm{~b}\end{array}$ & $\begin{array}{l}0.29 \\
0.04 \mathrm{a}\end{array}$ & $\begin{aligned}= & 6.6 \\
& 0.6\end{aligned}$ \\
\hline $\begin{array}{l}\text { Homogyne } \\
\text { alpina }\end{array}$ & $\begin{array}{ll}371 & \pm \\
19 \mathrm{a} & \end{array}$ & $\begin{array}{l}2.6 \\
0.0 \mathrm{~b}\end{array}$ & $\begin{array}{l}46 \pm 2 \\
b c\end{array}$ & $\begin{array}{ll}149 & \pm \\
6 \mathrm{~b} & \end{array}$ & $\begin{array}{l}94 \pm 2 \\
b c\end{array}$ & $\begin{array}{l}75 \pm 4 \\
b\end{array}$ & $\begin{array}{l}0.490 \\
0.025 \mathrm{ab}\end{array}$ & \pm & $\begin{array}{l}167 \\
29 \mathrm{bc}\end{array}$ & \pm & $\begin{array}{l}11 \pm \\
2 b\end{array}$ & $\begin{array}{l}1.95 \pm \\
0.07 \mathrm{a}\end{array}$ & $\begin{array}{l}0.73 \pm \\
0.02 \mathrm{~b}\end{array}$ & $\begin{array}{l}0.31 \\
0.02 \mathrm{a}\end{array}$ & $\begin{array}{l}7.3 \\
0.3\end{array}$ \\
\hline $\begin{array}{l}\text { Soldanella } \\
\text { aplina }\end{array}$ & $\begin{array}{l}291 \pm \\
22 \mathrm{ab}\end{array}$ & $\begin{array}{l}2.8 \\
0.1 \mathrm{~b}\end{array}$ & $\begin{array}{l}52 \pm 1 \\
a\end{array}$ & $\begin{array}{l}166 \pm \\
4 b\end{array}$ & $\begin{array}{l}102 \pm \\
3 \mathrm{ab}\end{array}$ & $\begin{array}{l}83 \pm 7 \\
b\end{array}$ & $\begin{array}{l}0.549 \\
0.036 \mathrm{ab}\end{array}$ & \pm & $\begin{array}{l}299 \\
42 a b\end{array}$ & & $\begin{array}{l}33 \pm \\
3 \mathrm{a}\end{array}$ & $\begin{array}{l}1.90 \pm \\
0.03 \mathrm{a}\end{array}$ & $\begin{array}{l}0.69 \pm \\
0.02 \mathrm{~b}\end{array}$ & $\begin{array}{l}0.16 \\
0.03 \mathrm{~b}\end{array}$ & $\begin{array}{l}6.5 \\
0.7\end{array}$ \\
\hline
\end{tabular}

